\title{
UNDERSTANDING SOCIAL INSTITUTIONS IN NEW WAYS
}

\section{Zulfakar}

Educational Administration Program, Faculty of Education Science and Psychology, Universitas Pendidikan Mandalika (UNDIKMA) Mataram Lombok, West Nusa Tenggara, Indonesia. e-mail: zulfakar07@gmail.com

ABSTRACT

In the world of education states that social construction theory looks at how learning obtained by students can provide understanding. Students can learn through the environment, then reflect on the understanding they get. In the world of education, it seems that it is encouraged to follow what is happening in society. Education is an institution that plays an important role in the social change. Social construction sees the meaning or motivation of students in pursuing knowledge because education is interpreted as the capital of one's social existence, Education is interpreted as capital to break the chain of poverty, education is interpreted as capital in finding work and education is interpreted as a legacy that will never end. Individuals or actors as if constructed that by gaining knowledge through the world of education they will be able to get a more decent life in time.

Keywords: social institutions, new ways.

\section{INTRODUCTION}

In the philosophy of science, ontology examines the nature of science which determines the nature, structure and nature of science. Ontology finds empirical facts, namely facts or problems to be studied, analyzing material objects from science, which are generally still empirical. Ontological discuss what you want to know and answer about what you want to know, questions that usually arise around ontology are: a) what is the object of knowledge to be studied; b) how the nature of the form of a particular object; and c) how the relationship between an object that has been studied with the general human comprehension, both from the way of thinking, sensing, which can produce knowledge. Whereas, regarding assumptions in empirical objects possessed by science are: a) have an assumption of similarity to a particular object, such as nature, shape and others; b) has the notion that a particular object has not changed in a certain period, such as the sun, earth; c) has the assumption that natural phenomena that occur are not accidental things, but rather are a certain pattern that is permanent with the same stages and sequences of events. Such events are commonly referred to by academics as 'determinism', which is usually understood by chance. From the perspective of Epistemology trying to answer how the process that allows the acquisition of knowledge in the form of science? What is the procedure? What things should pay attention, so that someone gets the knowledge right? What is called truth itself? What are the criteria? What method, technique or means help someone in gaining that knowledge in the form of science? Epistemology is part of philosophy, which in general the basis is reasoning or thought, science (science) itself is also based on reason with a focus on empiricism (reason to express empiricism). The foundation is empirical reasoning (there are measuring devices, there is a trial, there is experience), transcendental and empirical approaches are 
transcendental, using logic, statistics, and mathematics. Understanding obtained by humans through reason, senses, and others have separate methods in knowledge, theory, Among these are: a) Inductive methods; Inductive is a method that concludes statement of observations concluded in a more general statement. b) Deductive method; Deductive is a method that concludes that empirical data further processed in a statement system coherent. c) Positivism method; This method is rooted from what is already known.

Examples of application of Ontology and Epistemology in the world of education. 1\} Ontology, some examples of the application of ontology in the world of education: a) The ontology's view of the existence of a very broad real life, which can be said to be almost unlimited, views that experience is the key to human understanding. The application of ontology to this view, in the world of education is: during the learning process, so that someone can understand what is learned. They must experience it firsthand. To get firsthand experience, a person can be invited to carry out various activities, for example: experiments, observations, interviews, role-playing and others. b) The ontology view which suggests the existence of synthesis between science and religion becomes an understanding that uses spiritual foundation. The application in every learning activity carried out by the teacher, both in the classroom and outside the classroom, while inserting religious values, among others, at the time before and after the learning process, is done praying together, according to their respective religion, and beliefs. Another example is: in the lesson Civics, on the subject of mutual respect, are also given knowledge to respect the existence of followers of other religions. c) The view which states that education is not held centrally, but universally, given the situation and conditions in each place is different. The application is the enactment of Education Unit Level Curricula, at every level of education available, throughout the territory of the Republic of Indonesia, also an implementation of the view of ontology according to reconstructionism. Here every school has the right to determine indicators according to the situation, environment, and needs of students. In the world of education, the obligation of educators through an ontological background is to develop high and critical thinking power. The implication of the ontology view in education is that human experience must enrich its personality, not only for the universe and its contents, in the sense of everyday experience, but something that is almost unlimited.

2) Epistemology, Examples of the application of epistemology in the field of education economics, epistemology addresses questions such as how is the process that enables it to be obtained some knowledge? What is the procedure? What things must be considered for someone to get the right knowledge? Then what's true itself? What are the criteria? The characteristics of the methods used to gain knowledge in economics is: Economic subjects depart from facts or tangible symptoms. The fact shows that human needs continue to multiply, to almost unlimited, while economic resources as a means to meet human needs in number limited and increasingly rare. Not limited human needs, and the scarcity of economic resources can be found everywhere. Economics is able to explain these phenomena, because economics is built from the real world. Economic subjects develop theories to explain facts rationally. In order for humans to be able to read and explain economic phenomena systematically, economic concepts and theories are compiled into the building of economics. Besides fulfilling the requirements systematic, economics also meets the requirements other scientific objectives, and have a clear purpose. Generally the analysis used in economics is a problem solving method. The problem solving method is suitable for use in economic analysis because the object in economics is the basic problem of economics. The essence of economics is the best alternative. If the economic resources are abundant, then economics are not needed for human life. Likewise, with the use of certain economic resources (not used 
alternatively), economics is also not use again. - The birth of economics, because of the scarcity of sources of satisfying human needs.

Personal development is an educational activity to develop capabilities in the field of administration. The knowledge and skills implemented are aimed at long-term, so that administrative staff and develop knowledge that has been learned and practiced in educational organizations or other formal institutions. A few years earlier, in general the duties of the teacher were almost entirely related to the teaching work continued in the sense of conveying information and facts from the book to students, giving assignments, and checking it. At present, teachers must also pay attention to the interests of the school, participate in solving various problems faced by the school, which are sometimes very complex in nature. If asked from its function, the science of administration is broad in scope, carried out by every person and every group of organizations, in their activities, wherever they are, continuously, based on administrative science can make learning activities in the classroom more directed. Administrative contra many occur in practice in the field with other languages sometimes the administration of education does not run normally in an educational institution, even though it has been established and agreed with the previous leadership, due to the lack of member involvement and the lack of supporting infrastructure to carry out administrative activities that have been mutually agreed (Blackmore, 2010, Zulfakar, 2019) this happens a lot in informal , and formal educational institutions located in regions in Indonesia, the even in a number of developing countries in the world (Thrupp \& Willmott, 2003). In line with the comments submitted by Evers and Lakomski (1991: 214) that institutions are sometimes run irrationally even outside logic, and that is what causes failure in an educational institution.

\section{SOCIAL INSTITUTIONS}

In the process of normal functioning and community development, social institutions of education plays a very important role. Material and spiritual values, knowledge, experiences, traditions, accumulated by the work of previous generations, must be transferred to the new generation of people and assimilated by them. Therefore, maintaining the level of cultural development achieved, further improvement is not possible without mastering the cultural heritage of the past century. This problem is solved in the process of individual socialization, whose job is to familiarize someone with cultural norms and values , and turn them into full members of society. An important component of the individual socialization process is education, training a person to transfer accumulated knowledge and cultural values. Education can be described in more detail as a relatively independent system, "its function is the systematic training and education of community members, which focus on the mastery of certain scientific knowledge, ideological and moral values, skills, norms of behavior, the contents of which are determined by social-economic and political systems of the society, the level of material and technical development. In sociology, it is customary to distinguish between formal and non-formal education: The term "formal education" implies, first, the existence in a society of specialized institutions and organizations (schools from elementary to tertiary level) that carry out the learning process. Second, the education system prevailing in modern industrial societies is subject to certain models that are formally determined, as if "determining" the amount of knowledge acquired, learning certain skills and actions that must comply with: a) standard rules of an individual adopted in society certain, and b) regulatory requirements for the performance of general social roles in certain societies. Therefore, the functioning of the formal education system is determined by the cultural standards that apply in society, which are incorporated in the community of a country. In practice, it is often the legitimacy of science without anyone providing constructive input, so 
that sometimes it makes it too far or without social control from the surrounding community, this is what makes Martin Thrupp and in his memories with Richard Willmott (2003) in defending social apologists who conceptually very convincing to them. Whereas Mike Savage (2009) in his career journey equated his mindset with Clifford Geertz (1973), which is not in conflict with the thoughts conveyed by Gilbert Ryle (1971) in that, there is a tendency for social advice that is constructive, in social life, and thus the real application in the world of contemporary education administration.

\section{UNDERSTANDING INSTITUTIONS}

Among some people, sometimes scientific social communities are less desirable because of the political interests of certain social groups in a country, Mike Savage (2009: 163). The educational function refers to the contribution of education to the development and maintenance of education at different social levels, (Snyder, 2013, Colley et al., 2012, Duncheon \& Tierney, at the individual level of education helping students learn how to learn and help teachers how to teach. People educated are expected to have the awareness to learn throughout life, always feel left behind information, science , and technology so that they continue to be motivated to move forward and continue to learn (Helen Gunter \& Tanya Fitzgerald, 2008). Both one's social status (Jean-Francois Lyotard, 1984) and public respect for educated people (Lingad, 2010) are better than less educated, as well as in the world of administration which can serve as a means of control for policy makers in the world of education (Richard Bates, 1983). Education in the social aspect is required to perform three main functions. a) explanation function, i.e. explaining or giving understanding of phenomena which fall within the scope of the discussion. With complete and accurate information, you will gain a wider understanding and insight in interpreting the phenomena that are faced accurately. b) prediction function, which is predicting conditions and problems education that is expected to emerge in the future. In line with that, the demands of the community will change and develop due to the operation of internal and external factors that enter the community through various communication media. This prediction function is very necessary in planning educational development to anticipate the conditions, and challenges in the future. c) the function of utilization, which is handling problems faced in social life, such as employment problems, unemployment, social conflicts, and others that require support from the world of education, which is supported by instruments and variables related to the phenomenon of social life in a country (Robinson, Lloyd \& Rowe, 2008, John Hattie, 2009). In general, education in the social aspect aims to develop its function in social life, through assessment of the interrelation of social phenomena and education, to find a more functional model of education in people's lives.

Leadership in its function in the midst of organizational life (Brian Caldwell, 2007, Zulfakar, 2020) and social life in a general is as follows: a) facilitate freedom of thought and opinion, both individually and in groups, in an effort to collect data from group members, in an organization or society, who are able to meet the needs of group members, in the decisions, they make. Thus, the decision will be seen as an appropriate one, to be carried out by each group member (Stephen Dinham, 2007, Lawrie Drysdale and Helen Goode, 2010), to arrive at the goals set together; b) fostering an atmosphere of effective cooperation by giving appreciation and recognition to the abilities of people who are led, so that self-confidence arises, and willingness to respect others, in accordance with their abilities. In work, everyone knows their respective positions ,and functions, (Gronn, 2008) so that they are able to play the right role, in participating contributing, to the attainment of goals, both individually and through groups, in the process of collaboration; c) always provide mediation support for the occurrence of mutual understanding, with an attitude of respect for prices, so there is a 
feeling of being involved in group activities in the organization, and growing a sense of responsibility for the realization of their respective work, as a part of efforts to achieve goals; d) Help solve existing problems, both those faced individually and in groups (Gunter, 2010) by providing enlightenment in finding the best solution for the problem being faced.

\section{CONCLUSION}

Education Management is a systematic, systemic , and comprehensive collaborative process to realize educational goals. In addition, education management can also be interpreted as anything that is pleased with the management of the educational process to achieve the goals set by management both short-term, medium-term and long-term goals. Management is an integral component and cannot be separated from the whole education process. Because without management it is impossible for educational goals to be realized optimally, effectively \& efficiently. Within this framework there will be an awareness of the importance of education management that gives school and teacher authority to regulate education \& teaching, plan, organize, supervise, take responsibility, regulate, and lead Human Resources to help the implementation of learning in accordance with school goals. There is no field in this world that does not require management. Management is a series of activities that involve others in managing an organization, to achieve goals effectively and efficiently. Management activities have mushroomed , and penetrated every aspect of human life. Because, in essence, life consists of three main activities, namely: human activity ,and towards the goal, while management is managing the three main elements. Initially management developed in the economic field. The success of management in its role of achieving effective and efficient goals has brought extraordinary success in business. Then management is transformed into a number of other branches of science, including education. Educational management is a planning process. Organizing, implementing, directing and controlling in the world of education so that the objectives set can be achieved effectively and efficiently. Management of education that does not implement management is difficult to achieve expected goals. In fact, the implementation of management to the management of education becomes very important. Because education management will direct effectiveness in time, and cost efficiency, in all fields related to education.

\section{REFERENCES}

1. Benjamin H. Snyder, (2013). From vigilance to busyness: A neo-Weberian approach to clock time. Sociological Theory, 31(3), 243-266.

2. Brian J. Caldwell (2007), Educational leadership and school renewal: introduction by the guest editor. Australian Journal of Education,51(3), 225-227.

3. Clifford Geertz, (1973). The interpretation of cultures. London: Hutchinson.

4. Colin W. Evers and Gabriele Lakomski, (1991). Knowing educational administration: contemporary methodological controversies in educational administration research. New York, NY: Pergamon Press.

5. Colley, H., Henriksson, L., Niemeyer, B., \& Seddon, T. (2012). Competing time orders in human service work: towards a politics of time. Time \& Society,21(3), 371-394.

6. Duncheon, J. C., \& Tierney, W. G. (2013). Changing conceptions of time: Implications for educational research and practice. Review of Educational Research, 83(2), 236-272. 
7. Gilbert Ryle (1971). Collected papers. London: Hutchinson.

8. Helen Gunter, (2010). A sociological approach to educational leadership. British Journal of Sociology of Education, 31(4), 519-527.

9. Helen Gunter, \& Fitzgerald, T. (2008). Educational administration and history part 1: Debating the agenda. Journal of Educational Administration and History, 40(1), 5-21.

10. Jean-François Lyotard, (1984). The postmodern condition: A report on knowledge (G. Bennington \& B. Massumi, Trans.). Minneapolis: University of Minnesota Press. [Originally published as La condition postmoderne: rapport sur le savoir (Paris: Les Editions de Minuit).]

11. John Hattie, (2009). Visible learning: a synthesis of over 800 meta-analyses relating to achievement. London: Routledge.

12. Lingard, B. (2010). Policy borrowing, policy learning: Testing times in Australian schooling. Critical Studies in Education, 51(2), 129-147.

13. Martin Thrupp \& Willmott, R. (2003). Education management in managerialist times. Maidenhead, England: Open University Press.

14. Mike Savage, (2009). Contemporary sociology and the challenge of descriptive assemblage. European Journal of Social Theory, 12(1), 155-174.

15. Peter Gronn, (2008). The state of Denmark. Journal of Educational Administration and History, 40(2), 173-185.

16. Pierre Bourdieu, (2004). Science of science and reflexivity (R. Nice, Trans.). Cambridge, UK: Polity Press. [Originally published as Science de la science et réflexivité (Paris: Éditions Rasions d'Agir)].

17. Richard J. Bates' (1983). Educational administration and the management of knowledge. Geelong, Vic: Deakin University Press.

18. Robinson, V. M. J., Lloyd, C. A., \& Rowe, K. J. (2008). The impact of leadership on student outcomes: An analysis of the differential effects of leadership types. Educational Administration Quarterly, 44(5), 635-674.

19. Stephen Dinham (2007). The secondary head of department and the achievement of exceptional student outcomes. Journal of Educational Administration, 45(1), 62-79.

20. Zulfakar, (2019). The Leadership of Headmaster in Praya Public Elementary Schools, Central Lombok-west Nusa Tenggara-Indonesia, International Journal of Scientific \& Technology Research 8(12), 468-474.

21. Zulfakar, (2020). Understanding about the teacher as a flexible technicians, International Journal of Multicultural and Multireligious Understanding, 7(3), 193-205. 